\title{
Brazilian Journal

\section{TREATMENT OF THE EFFLUENT FROM A KRAFT BLEACH PLANT WITH THE WHITE-ROT FUNGUS Pleurotus ostreatoroseus SING}

\author{
A.Z.Santos, C.R.G. Tavares ${ }^{*}$ and S.M.Gomes-da-Costa \\ State University of Maringá, Av. Colombo 5790, 87020-900, \\ Phone: (55) (044)261-4345, Fax: (55)( 044)261-4347 \\ Maringa - Paraná, Brazil
}

(Received: March 5, 2002 ; Accepted: August 7, 2002)

\begin{abstract}
The ligninolytic fungus Pleurotus ostreatoroseus (synonymy of Pleurotus ëous) was used to treat the first alkali extraction stage (E1) effluent of a kraft bleach plant. It was pelletized and used for two continuous experiments in a two-liter turbulent-flow bioreactor. In the first experiment, the average removal of color and of total phenols was 18.6 and $11.6 \%$, respectively, after the addition of glucose. During the second experiment, which was developed with the addition of several quantities of glucose, the maximum removal of color, of total phenols and of lignin/chlorolignin was 19.4, 9.4 and $44.5 \%$. For both experiments, the best results were obtained when the effluent was diluted and enriched with glucose. This indicated the need for an extra carbon source for the fungal treatment. Using the mycelial mass in suspension, three experiments were carried out. The best results were obtained with $20 \%$ fungus and shaking of the effluent. During the last three days of the experiment the average removal of color, of total phenols and of lignin/chlorolignin was $84.4 \pm 6.1,82.1 \pm 5.7$ and $72.4 \pm 8.9$, respectively. The results indicate the potential of Pleurotus ostreatoroseus for use in the treatment of E1 effluent.

Keywords: kraft effluent, fungal treatment, Pleurotus ëou.
\end{abstract}

\section{INTRODUCTION}

Bleached kraft pulp and paper mills produce large quantities of brown-colored effluents as a result of the different processes applied to wood and pulp. These effluents contain many chlorinated organic compounds, the chlorolignins, which are responsible for their brown color and originate in the residual lignin degradation during the process of bleaching the pulp (Esposito et al., 1991; Prouty, 1990).

The organic compounds in these effluents, mainly the chlorinated phenols, are toxic to aquatic organisms and resistant to microbial degradation. The chlorolignins can be slowly degraded to units with low molecular mass, such as catechol and guaiacol, and be damaging to the environment (Eriksson \& Kolar, 1985). The brown color of the effluents obstructs penetration of the water by sunlight and can inhibit the biological activities in it (Esposito et al., 1991).

These effluents are usually treated in aerated lagoons and actived sludges by biological processes which reduce the chemical oxygen demand (COD) and the biological oxygen demand (BOD), but are not efficient in reducing color, chlorophenols and high-molecular-weight chlorolignins (Cammarota, 1991).

Many studies have demonstrated that the color and the chlorinated organic compounds of kraft effluents can be reduced by white-rot fungi, which are considered promising for the treatment of these effluents (Prouty, 1990; Cammarota, 1991; Esposito, 1991). A process that has been extensively studied is the Mycor (Mycelial Color Removal) process, which

*To whom correspondence should be addressed 
uses Phanerochaete chrysosporium Burds immobilized on a rotactory biological contactor (RBC) (Esposito, 1991). Pellinen et al. (1988) used this process and obtained $65 \%$ decolorization and $33 \%$ COD reduction in two days, using E1 effluent with a mineral and nutrient solution in addition to 10 $\mathrm{g} / \mathrm{L}$ of glucose.

In a search for more efficient and ecomonomically practicable processess, other bioreactors and ligninolitic fungi have been studied. Cammarota (1991) used the same fungus immobilized on polyurethane foam in a fixed-bed bioreactor. The author used diluted effluent with nutrients and obtained 70\% decolorization, a $64 \%$ average reduction of total phenols and a 50\% average reduction of COD. The average hydraulic retention time of the reactor was 5.8 days.

The fixed-bed bioreactor was also used by Esposito (1991). The E1 effluent was treated by Lentinus edodes immobilized on nylon and on wood under a batch system. After $120 \mathrm{~h}$ of experiment, using the fungus immobilized on nylon, there was $70 \%$ decoloration, a $36 \%$ reduction of total phenol and a $67 \%$ reduction of COD. And, after the same period, there was $42 \%$ decolorization and a $25 \%$ reduction of total phenols using the fungus immobilized on wood.

In this work, the fungus Pleurotus ëous was studied. It was pelletized and used in a turbulent flow reactor for removal of color, total phenols and lignin/chlorolignin from a first alkali-extractionstage effluent from a kraft bleach pulp and paper mill. Its mycelial mass, which was not pelletized, was used in batch experiments to treat the same effluent.

\section{METHODS}

\section{Microorganism and Media}

Pleurotus ëous CCB016, a strain of Pleurotus ëous (Berk.) Sacc. isolated in Brazil, was provided by IBt Culture Collection (Instituto de Botânica do Estado de São Paulo), and the stock culture was maintained on PDA (potato-dextrose-agar) medium at $5^{\circ} \mathrm{C}$. Fungus, which was grown at PDA for seven to ten days, was inoculated in $30 \mathrm{~mL}$-tubes containing $10 \mathrm{~mL}$ of liquid medium (potatodextrose). After seven to ten days, the mycelial mass and the medium were transferred to $250 \mathrm{~mL}$ conical shake flasks, which contained $90 \mathrm{~mL}$ of liquid medium. Flasks were shaken for seven days at 120 $\mathrm{rpm}$ and $30^{\circ} \mathrm{C}$ to form the pellets. The flasks were also incubated at $30^{\circ} \mathrm{C}$ without shaking for five days only to form the mycelial mass.

\section{Effluent and Reactor}

The E1 effluent was obtained from a kraft pulp and paper mill. It was collected, filtered through a $0.5 \mathrm{~mm}$ sieve to remove large suspended particles and stored at $-5^{\circ} \mathrm{C}$ until use. The characteristics of the collected sample were $838.02 \mathrm{mg} / \mathrm{L}$ of COD, 9.5 $\mathrm{pH}, 6666.67 \mathrm{CU}$ (color units), $0.12 \mathrm{mg} / \mathrm{L}$ of glucose, $42.35 \mathrm{mg} / \mathrm{L}$ of lignin/chlorolignin and $40.92 \mathrm{mg} / \mathrm{L}$ of total phenols.

The reactor was a $2000 \mathrm{~mL}$ acrylic cylinder. Aeration and mixing were carried out by a fine stone diffuser placed on the bottom of the reactor. The flow rate of compressed air to the diffuser, which was regulated by a rotameter, was $0.60 \mathrm{~L} / \mathrm{min}$. The reactor was fed near its bottom by a peristaltic pump and the effluent in the reactor was maintained at ambient temperature.

\section{Continuous Biotreatment}

After being filtered, the pellets were aseptically inoculated in the reactor at a proportion of $10 \%$ of the reactor volume. After a $48 \mathrm{~h}$ inoculation, the reactor was fed continuously and effluent samples were taken every $24 \mathrm{~h}$ at the inlet and outlet of the bioreactor. Two experiments were carried out. The first one took 26 days and effluent samples was used to analyze $\mathrm{pH}$, color and total phenols. In the second one, with a 42-day duration time, $\mathrm{pH}, \mathrm{COD}$, sugar, color, total phenols and lignin/chlorolignin concentration were analyzed. The hydraulic retention time $\left(t_{r}\right)$ of the first experiment was two days. For the second experiment, it was two days until the 28th day and four days from the 28th to 42th day.

During the experiments, the reactor was fed with effluent at different dilutions and concentrations of glucose. The experimental conditions and the results of the first and second experiments are summarized in Table 1.

\section{Batch Biotreatment}

After being filtered, the mycelial mass was inoculated in the effluent according to the conditions shown in Table 2. The batch experiments were carried out for five days in $500-\mathrm{mL}$ beakers containing 500 $\mathrm{mL}$ of effluent at ambient temperature. The mixed effluent was mixed by magnetic shaker. The $\mathrm{pH}$ was adjusted with sulfuric acid to between 6 and 7 . Throughout the experiments, $15-\mathrm{mL}$ samples were 
collected every $24 \mathrm{~h}$ for analysis of $\mathrm{pH}$, color, total phenols and lignin/chlorolignin concentration.

\section{Analytical Methods}

Determination of chemical oxygen demand (COD) was carried out by the APHA standard micromethod, adapted by Tavares (1992). Color was measured as absorbance in platinum cobalt units at $465 \mathrm{~nm}$ and $\mathrm{pH} 7.6$ and total phenols was determined by the Folin-Ciocalteu method, as described by Esposito (1991). Sugar was determined by the modified DNS procedure (Moraes \& Zanin, 1987). Concentration of lignins and/or chlorolignins was estimated by measuring the absorbance of the solution at $280 \mathrm{~nm}$ and under the assumption that of Beer's law is valid (Wang et al., 1992). pH was measured using a digital potenciometer.

\section{RESULTS AND DISCUSSION}

The first experiment, which is presented in Table 1, was initiated with concentrated effluent without any extra source of carbon. There was effluent $\mathrm{pH}$ neutralization and average removal of color and total phenols of 13.8 and $3.8 \%$. By the end of the fifth day there was no reduction of color or total phenols, so the reactor was aerated and fed with $50 \%$ diluted effluent. Then, it was fed with $50 \%$ diluted effluent which was enriched with glucose. At first, the glucose was consumed by the fungus, which is indicated by a COD removal of $73.7 \%$, and then there was an $18.6 \%$ removal of color and an $11.6 \%$ removal of total phenols. The diluted effluent without glucose was again fed into the reactor and performance of the fungus was worse than the previous one.

The second experiment (Table 1) was initiated with $50 \%$ diluted effluent with $10 \mathrm{~g} / \mathrm{L}$ of glucose. The fungus consumed the glucose and there was a $44.5 \%$ removal of lignin/chlorolignin but no removal of color and total phenols. So the effluent was aerated and the reactor was fed with concnetrated effluent. Between the sixth and fourteenth days there was no removal of COD or glucose, but there was a $17.3 \%$ removal of color, a $5.6 \%$ removal of total phenols and a $14.3 \%$ removal of lignin/chlorolignin at an acidic $\mathrm{pH}$ of 5.3. After that period, glucose was fed into the reactor and consumed by the fungus, but there was no removal of color, lignin/chlorolignin or total phenols. Therefore the reactor was fed with $50 \%$ diluted effluent with 1 and $10 \mathrm{~g} / \mathrm{L}$ of glucose. Despite the consumption of glucose by the fungus, its performance did not improve. On the $27^{\text {th }}$ day, the hydraulic retention time of the reactor was increased to four days, which increased the contact time of the effluent with the fungus. After that, the reactor was fed only with diluted effluent and there was a $13 \%$ removal of color and a $7.9 \%$ removal of lignin/chlorolignin. Then the reactor was again fed with diluted effluent with $10 \mathrm{~g} / \mathrm{L}$ of glucose and removal of $55.6 \%$ COD, $68.5 \%$ glucose, $19.4 \%$ color, $9.4 \%$ total phenols and $19.5 \%$ lignin/chlorolignin ocurred at an acidic $\mathrm{pH}$ of 4.4.

Results of the continuous experiments results indicated that the feed of concentrated effluent damaged the performance of the fungus despite the addition of glucose to the effluent.

The results of the batch experiments (Table 2) indicated that the best treatment using the fungus in suspension was the second one. Due to the shaking used during this experiment, the entire mycelial mass was fragmented. The small particles were maintained in suspension by the shaking to avoid sedimentation. This fragmentation of the mycelial mass, which increased the area of contact between effluent and oxygen, and the amount of fungus was probably responsible for these results being the best.

Experiments one and three showed, besides the behavior, similar results. All these results indicated that the initial $\mathrm{pH}$ adjustment did not affect treatment of the effluent under the conditions of those experiments.

The decolorization results obtained with Pleurotus ëous in suspension under the conditions of the second experiment, were better than the results obtained with other fungi. Esposito et al. (1991) obtained 73\% color removal after five days of treatment. The authors used diluted E1 effluent without an extra carbon source and the fungus Lentinus edodes. Using Coriolus versicolor, Livernoche et al. (1983) obtained 60\% decolorization using the fungus in liquid culture, and $80 \%$ with the fungus immobilized on calcium alginate. They used E1 effluent enriched with glucose. The results obtained during that experiment were also better than the ones obtained by Archibald et al. (1990). The authors used Coriolus versicolor and E1 effluent with $20 \mathrm{mM}$ of glucose, obtaining $80 \%$ decolorization. The decoloration results of the second experiment are comparable to those obtained by Wang et al. (1992), who used the fungus Ganoderma lacidum. In experiments with the E1 effluent diluted and enriched with nutients and $5 \mathrm{~g} / \mathrm{L}$ of glucose, the authors obtained $88 \%$ color reduction after four days of treatment. In their experiments Livernoche et al. (1983) and Archibald et al. (1990) used in their experiments the fungi cultivated in media enriched with nutrients and 
glucose. In addition to the medium enriched with nutrients, Wang et al. (1992) used E1 effluent diluted and enriched with nutrients and glucose.

For the experiments using the fungus in suspension, concentrated effluent was used without addition of an extra carbon source or nutrients and the fungus was cultivated in PDA without the addition of nutrients. Considering these facts, the results obtained in this study were better than those obtained in others.

Table 1: Experimental conditions and results obtained throughout the continuous experiments.

\begin{tabular}{|c|c|c|c|c|c|c|}
\hline \multicolumn{7}{|c|}{ First Experiment } \\
\hline \multirow{2}{*}{\multicolumn{2}{|c|}{$\begin{array}{c}\text { Experiment } \\
\text { days }\end{array}$}} & \multirow{2}{*}{$\begin{array}{c}\text { Reactor } \\
\text { Feed }\end{array}$} & \multirow{2}{*}{$\begin{array}{c}\text { Reactor effluent } \\
\text { pH }\end{array}$} & \multicolumn{3}{|c|}{ Average removal (\%) } \\
\hline & & & & \multicolumn{2}{|c|}{ Color } & Total phenols \\
\hline \multicolumn{2}{|c|}{$1^{\text {st }}-4^{\text {th }}$} & $\mathrm{CE}^{a}$ & 7.0 & \multicolumn{2}{|c|}{13.8} & 3.8 \\
\hline \multicolumn{2}{|l|}{$5^{\text {th }}-8^{\text {th }}$} & $\mathrm{DE}^{b}$ & 8.4 & \multicolumn{2}{|c|}{-} & - \\
\hline \multicolumn{2}{|c|}{$9^{\text {th }}-14^{\text {th }}$} & $\mathrm{DE}-10^{c}$ & 8.6 & \multicolumn{2}{|c|}{-} & - \\
\hline \multicolumn{2}{|c|}{$15^{\text {th }}-19^{\text {th }}$} & $\mathrm{DE}-10$ & 5.7 & \multicolumn{2}{|c|}{18.6} & 11.6 \\
\hline \multicolumn{2}{|c|}{$20^{\text {th }}-26^{\text {th }}$} & $\mathrm{DE}$ & 5.9 & \multicolumn{2}{|c|}{8.3} & - \\
\hline \multicolumn{7}{|c|}{ Second Experiment } \\
\hline \multirow{2}{*}{$\begin{array}{l}\text { Exp. } \\
\text { Days }\end{array}$} & \multirow{2}{*}{$\begin{array}{c}\text { Reactor } \\
\text { feed }\end{array}$} & \multirow{2}{*}{$\begin{array}{c}\text { Reactor } \\
\text { effluent } \\
\text { pH }\end{array}$} & \multicolumn{4}{|c|}{ Average removal (\%) } \\
\hline & & & Glucose & Color & $\begin{array}{c}\text { Total } \\
\text { phenols }\end{array}$ & $\begin{array}{c}\text { Lignin/ } \\
\text { chlorolignin }\end{array}$ \\
\hline $1^{\text {st }}-5^{\text {th }}$ & $\mathrm{DE}-10$ & 7.3 & 41.9 & - & - & 44.5 \\
\hline $6^{\text {th }}-14^{\text {th }}$ & $\mathrm{CE}$ & 5.3 & - & 17.3 & 5.6 & 14.3 \\
\hline $15^{\text {th }}-17^{\text {th }}$ & CE -0.1 & 8.3 & 36.62 & - & - & - \\
\hline $17^{\text {th }}-21^{\text {st }}$ & $\mathrm{CE}-0.5$ & 8.0 & 80.1 & - & - & - \\
\hline $22^{\text {nd }}-24^{\text {th }}$ & DE & 8.1 & - & - & - & - \\
\hline $24^{\text {th }}-26^{\text {th }}$ & $\mathrm{DE}-1$ & 7.9 & 90.3 & - & - & - \\
\hline $27^{\text {th }}$ & DE - 10 & 7.2 & 87.3 & - & - & - \\
\hline $28^{\text {th }}-33^{\text {rd }}$ & $\mathrm{DE}$ & 5.3 & - & 13.0 & - & 7.9 \\
\hline $34^{\text {th }}-42^{\text {nd }}$ & DE - 10 & 4.4 & 68.5 & 19.4 & 9.4 & 19.5 \\
\hline
\end{tabular}

Table 2: Experimental conditions and results obtained throughout the batch experiments.

\begin{tabular}{|c|c|c|c|}
\hline Experiment & $\mathbf{1}$ & $\mathbf{2}$ & $\mathbf{3}$ \\
\hline Mycelial mass (\% v/v) & 10 & 20 & 10 \\
Shaking & No & Yes & No \\
Adjustment of initial pH & Yes & Yes & No \\
$\mathrm{pH}$ & $4.8 \pm 0.2$ & $3.9 \pm 0.1$ & $4.8 \pm 0.3$ \\
Color removal (\%) $^{a}$ & $32.9 \pm 7.2$ & $84.4 \pm 6.1$ & $32.4 \pm 12.7$ \\
Total phenols removal (\%) $^{a}$ & $39.3 \pm 3.2$ & $82.1 \pm 5.7$ & $31.9 \pm 1.6$ \\
Lignin/chlorolignin removal (\%) $^{a}$ & $32.6 \pm 8.3$ & $72.4 \pm 8.9$ & $29.8 \pm 7.9$ \\
\hline
\end{tabular}

${ }^{a}$ After the third day 


\section{CONCLUSIONS}

According to the results obtained during the continuous experiments, an extra carbon source must be added to the effluent and the effluent must be diluted. Thus, the process of reduction of color, of total phenols and of lignin/chlorolignin was better developed when the effluent was diluted and enriched with glucose. The processes of removal of color, of total phenols and of lignin/chlorolignin were interdependent, which was pointed out by their similar behaviors during the experiments. The efficient treatment of the E1 effluent by Pleurotus ëous occurred in acid medium. For the batch and continuous experiments, the $\mathrm{pH}$ was between 3.9 and 5.0 during the periods of efficient treatment. Using the mycelial mass in suspension, the best results were obtained with the largest quantity of fungus and with the shaking of the effluent, which caused fragmentation of the mycelial mass and better contact with the effluent oxygen. It was not necessary to adjust the initial $\mathrm{pH}$ of the effluent. All these results point to the potentiality of Pleurotus ëous to treat the effluent from bleached kraft pulp and paper mills. It is easy to cultivate and special conditions are not needed. This fact makes it potentially applicable to the control of pollution. This research, however, needs further confirmation and otimization of the treatment process.

\section{ACKNOWLEDGMENT}

Financial support from CAPES is acknowledged.

\section{REFERENCES}

Archibald, F., Paice, M. G. \& Jurasek, L. (1990). Decolorization of Kraft Bleachery Effluent Chromophores by Coriolus (trametes) versicolor. Enzyme Microb. Technol. 12: 846-853.

Cammarota, M. C. (1991). Avaliação de um bio- reator fúngico para remoção de cor do efluente do branqueamento de polpa kraft. Master's thesis, ESCOLA DE QUÍMICA/UFRJ, Rio de Janeiro, RJ.

Eriksson, K. E. \& Kolar, M. C. (1985). Microbial Degradaton of Chlorolignin. Environ Sci Technol 19: 1086-1089.

Esposito, E. (1991). Processos envolvidos no tratamento biológico de efluentes: utilização de um biorreator de leito recheado. Master's thesis, FEQ/UNICAMP, Campinas, SP.

Esposito, E., Canhos V. P. \& Durán, N. (1991). Screening of Lignin-degrading Fungi for Removal of Color from Kraft Mill Wastewater with no Additional Extra Carbon-Source. Biotechnol. Letters 13: 571-576.

Livernoche, D., Jurasek, L., Desrochers, M. \& Dorica, J. (1983). Removal of Color from Kraft Mill Wastewaters with Cultures of White-rot Fungi and with Immobilized Mycelium of Coriolus versicolor. Biotech. and Bioeng. 25: 2055-2065.

Moraes, F. F. Zanin, G. M. Tecnologia de imobilização de células e enzimas aplicadas à produção de álcool de biomassa. Relatório $\mathrm{n}^{\circ} 02$. DEQ-UEM, Maringá - Paraná.

Pellinen, J., Joyce T. W. \& Chang H-M. (1988). Dechlorination of high-Molecular-Weight Chlorolignin by the White-rot Fungus $P$. chrysosporium. Tappi journal 71: 191-194.

Prouty, A. L.(1990). Bench-scale Development and Evaluation of a Fungal Bioreactor for Color Removal from Bleach Effluents. Appl Microbiol 32: 490-493.

Tavares, C. R. G. (1992). Tratamento aeróbio de efluentes em bio-reatores de leito fluidizado trifásico. Ph.D. diss., COPPE/UFRJ, Rio de Janeiro, RJ.

Wang, S-H., Ferguson, J. F. \& McCarthy, J. L. (1992). The Decolorization and Dechlorination of Kraft Bleach Plant Effluent Solutes by Use of Three Fungi: Ganoderma lacidum, Coriolus versicolor and Hericium erinaceum. Holzforschung 46: 219223. 